\title{
Folate deficiency and aberrant expression of cell adhesion molecule 1 are potential indicators of prognosis in laryngeal squamous cell carcinoma
}

\author{
HAO CHANG ${ }^{1}$, MIN MA $^{1}$, RUI MA ${ }^{2}$, CHAO ZHANG $^{1}$, WEI ZENG ${ }^{1}$ and LU QI XING ${ }^{3}$ \\ ${ }^{1}$ Department of Otolaryngology, The First Affiliated Hospital, College of Clinical Medicine of Henan University of Science \\ and Technology, Luoyang, Henan 471003; ${ }^{2}$ Department of Central Laboratory, \\ Eye \& ENT Hospital of Fudan University, Shanghai 200032; ${ }^{3}$ Department of Pathology, \\ The First Affiliated Hospital and College of Clinical Medicine of Henan University of Science and Technology, \\ Luoyang, Henan 471003, P.R. China
}

Received July 10, 2015; Accepted August 19, 2016

DOI: $10.3892 / \mathrm{ol} .2016 .5264$

\begin{abstract}
The etiology of laryngeal squamous cell carcinoma (LSCC) has not yet been adequately examined. Therefore, the present study aimed to investigate the association between serum folate deficiency and abnormal expression of the cell adhesion molecule 1 (CADM1) protein in the progression of LSCC. Samples were collected from 60 patients with LSCC and 30 healthy people. Radioimmunoassays and immunohistochemical staining were performed to measure serum folate levels and CADM1 protein expression, respectively. The results demonstrated that CADM1 expression in LSCC specimens was significantly lower than in adjacent normal tissues $\left(\chi^{2}=28.229, \mathrm{P}<0.001\right)$, which was associated with histological differentiation and clinical stage $(\mathrm{P}=0.010$ and 0.020 , respectively). Levels of serum folate in patients with LSCC were significantly lower than those observed in healthy individuals $(\mathrm{P}=0.002)$. Furthermore, TSLCl expression and serum folate levels were positively correlated in $\operatorname{LSCC}(r=0.642, \mathrm{P}=0.001)$. Thus, the present study determined that decreased CADM1 protein expression and low levels of serum folate were correlated with an increased severity of LSCC.
\end{abstract}

\section{Introduction}

Laryngeal squamous cell carcinoma (LSCC) is one of the most common malignant tumors identified in the head and neck. LSCCs account for $90 \%$ of all larynx carcinomas, $90 \%$

Correspondence to: Dr Min Ma, Department of Otolaryngology, The First Affiliated Hospital, and College of Clinical Medicine of Henan University of Science and Technology, 24 Jing Hua Road, Luoyang, Henan 471003, P.R. China

E-mail:minma33@sina.com

Key words: folate, cell adhesion molecule 1, laryngeal squamous cell carcinoma of which are in males. Furthermore, the majority of patients are aged between 40 and 60-years-old (1). At present, there is no specific biomarker for LSCC diagnosis and prognosis. Thus, the current study aimed to examine potential biomarkers that could improve the early diagnosis of LSCC.

The cell adhesion molecule 1 (CADMI) gene encodes a membrane protein, which is silenced in $\sim 44 \%$ of patients with non-small cell lung cancer and $30-60 \%$ of those with other types of cancer (2). Previous studies have identified two mechanisms of CADMI inactivation: Promoter hypermethylation and loss of heterozygosity (3-5). Furthermore, it has been demonstrated that the CADM1 protein participates in a number of biological functions, including synapse formation, cell adhesion and tumor suppression (6). In several types of tumors, the absence of CADM1 expression is closely related to invasive tumor behavior (6-9). However, the role of CADM1 in LSCC remains largely unknown. To investigate the association between CADM1 protein expression and the development of LSCC, 60 surgically resected specimens were collected and assessed for loss of the CADM1 protein using immunohistochemistry. Subsequently, the association of CADM1 protein expression with LSCC clinicopathological parameters and the histological growth pattern of the tumors were investigated.

Folate is a water-soluble B vitamin that mediates one-carbon metabolism in vivo and serves multiple functions in physiological processes. Folate provides one-carbon groups for DNA replication, epigenetic modifications and DNA mutation prevention, thus protecting against tumorigenesis (10). Additionally, tetrahydrofolate synthesis in vivo requires folate for blood cell development and maturation (11). Folate deficiency is closely associated with glossitis, anemia and, in pregnancy, fetal neural tube defects (12). Previous studies have suggested that folate may aid cancer prevention $(13,14)$, and several studies have demonstrated that a reduction in serum folate levels may be closely related to several types of cancer, including colorectal cancer (15-17). However, no similar report in LSCC was found in the literature. Therefore, it is necessary to investigate the relationship between serum folate levels and 
cancer progression and prognosis. The present study aimed to investigate the underlying association between folate deficiency and CADM1 protein expression in LSCC.

\section{Patients and methods}

Patients and tissue specimens. A total of 60 pairs of LSCC and precancerous specimens were collected from patients treated at the Department of Otolaryngology, Head and Neck Surgery at the First Affiliated Hospital of Henan University of Science and Technology (Luoyang, China) between September 2011 and September 2014. The control group consisted of 30 healthy volunteers whose blood was collected during routine health examinations. The ratio of patients to healthy volunteers was 1:2. Precancerous tissues were defined as the laryngeal mucosa $2 \mathrm{~cm}$ from the edge of the cancerous site. Patients had undergone preoperative partial or total laryngectomy without radical and chemical therapies. Patients with megaloblastic anemia or other types of anemia, upper gastrointestinal tract diseases, and those treated with any other surgical procedures, were excluded. Patients with a history of smoking, oral contraceptive use or those who had taken B vitamins in the past 6 months were also excluded from the current study. The Ethics Committee of the First Affiliated Hospital of Henan University of Science and Technology (Luoyang, China) approved the use of human tissues for the current study. All patients and volunteers provided written informed consent to participate.

Immunohistochemistry. Expression of the CADM1 protein was tested using an Immunohistochemical S-P kit against CADM1 (Kangwei Bio, Ltd., Beijing, China), according to the manufacturer's protocol. A rabbit polyclonal antibody against CADM1 (1:100 dilution, cat. no. Rs-1147R) was purchased from Kangwei Bio, Ltd. Tissues were fixed with $10 \%$ formaldehyde solution, cut into $3-\mu \mathrm{m}$ sections, embedded in paraffin blocks and subsequently incubated with the polyclonal antibody at $4^{\circ} \mathrm{C}$ overnight ( $>14 \mathrm{~h}$ ). Sections were subsequently incubated with biotinylated goat anti-rabbit immunoglobulin G (1:100 dilution, cat. no. CW2035S; Kangwei Bio, Ltd.) for $40 \mathrm{~min}$ at room temperature. Phosphate-buffered saline was used as a negative control. 3,3'-diaminobenzidine was used to stain the sections and hematoxylin was used as a counterstain to highlight the cytoblasts and background color. Each section was observed in 10 random fields under x200 magnification (18). The score was calculated by adding the scores for intensity (weak $=1$, moderate $=2$, intense $=3$ ) and proportion $(5 \%=1,6-24 \%=2,25-49 \%=3,50-74 \%=4, \geq 75 \%=5)$ of positively stained cells (19). Scores of $\geq 2$ were considered positive. Two independent pathologists assessed each slide.

Radioimmunoassay. Whole blood samples $(6 \mathrm{ml})$ were drawn from a peripheral vein of each participant after overnight fasting. Following the centrifugation of whole blood samples at $300 \times \mathrm{g}$ for $15 \mathrm{~min}$, serum samples were collected and stored at $-80^{\circ} \mathrm{C}$ until analysis. Serum folate levels were tested using radioimmunoassay quantification with a commercial kit for measurement of folate (Shanghai Ruiqi Bio-Technology, Co., Ltd., Shanghai, China), according to the manufacturer's instructions.
Table I. Expression of the CADM1 protein in laryngeal squamous cell carcinoma and adjacent normal tissues.

\begin{tabular}{lccccc}
\hline & & \multicolumn{2}{c}{ CADM1 } & & \\
\cline { 3 - 5 } Group & $\mathrm{n}$ & Positive & Negative & $\chi^{2}$ & P-value \\
\hline Tumors & 60 & 12 & 48 & 28.229 & $0.001^{\mathrm{a}}$ \\
$\begin{array}{l}\text { Adjacent } \\
\text { normal tissues }\end{array}$ & 60 & 47 & 13 & & \\
\hline
\end{tabular}

${ }^{\mathrm{a}} \mathrm{P}<0.01 ; \mathrm{n}$, number of samples; CADM1, cell adhesion molecule 1.

Statistical analysis. Data were analyzed using Student's $t$-test, $\chi^{2}$ test, one-way analysis of variance (ANOVA), Student-Newman-Keuls test, Fisher's exact test and Spearman's rank correlation coefficient. SPSS version 16.0 for Windows (SPSS Inc., Chicago, IL, USA) was used to analyze all results. $\mathrm{P}<0.05$ was considered to indicate a statistically significant difference.

\section{Results}

Expression of the CADM1 protein in LSCC. CADM1 protein expression was detected via immunohistochemical analysis of 60 malignant squamous cells of larynx tumors and 60 corresponding healthy adjacent non-neoplastic tissues, which were examined as a comparison. The results demonstrated that 47 specimens $(78 \%)$ of adjacent normal tissues expressed CADM1 protein. By contrast, only 12 tumor specimens $(20 \%)$ expressed the CADM1 protein $(\mathrm{P}<0.001$; Table I). The associations among CADM1 expression patterns in the tumors, serum folate levels and patient clinical characteristics are presented in Table II. Positive staining indicated that CADM1 was primarily located in the cytoplasm in the adjacent normal tissues, but was absent in the tumor tissues (Fig. 1A and B, indicated by shapes). Expression of the CADM1 protein was not correlated with patient age or anatomic localization $(\mathrm{P}=1.000$ and 0.386 , respectively), but was correlated with histological differentiation and clinical stage $(\mathrm{P}=0.010$ and 0.020, respectively; Table II).

Associations among patient characteristics, expression of CADM1 and serum folate levels. One-way ANOVA was used to determine differences in the serum folate levels among LSCC tissues with different clinical characteristics, including age, clinical stage, histological differentiation and anatomic localization. The differences were statistically significant among tumor tissues with different clinical stages, histological differentiation and anatomic localizations $(\mathrm{P}=0.001$, 0.001 and 0.001 , respectively; Table II). To further clarify the relationship between serum folate levels and stage of LSCC, a Student-Newman-Keuls test was used for multiple comparisons of clinical stage, histological differentiation and anatomic localization. The results indicated that serum folate levels decreased as tumor malignancy increased (Table III). Additionally, serum folate levels were significantly lower in patients with LSCC compared with healthy control subjects $(\mathrm{P}=0.002$; Table IV). The spearman correlation analysis identified a 
Table II. Associations among patient clinical characteristics, protein expression of CADM1 and serum folate levels.

\begin{tabular}{|c|c|c|c|c|c|c|}
\hline Characteristic & $\mathrm{n}$ & $\mathrm{P}$ & $\mathrm{N}$ & $\begin{array}{l}\text { Folic acid } \\
\text { (ng/ml) }\end{array}$ & $\begin{array}{c}\text { P-value: } \\
\text { Fisher's exact test }\end{array}$ & $\begin{array}{c}\text { P-value: } \\
\text { One-way ANOVA }\end{array}$ \\
\hline \multicolumn{7}{|l|}{ Age (years) } \\
\hline$\geq 50$ & 49 & 15 & 34 & $3.53 \pm 1.53$ & & \\
\hline$<50$ & 11 & 3 & 8 & $2.36 \pm 0.98$ & 1.000 & 0.058 \\
\hline \multicolumn{7}{|l|}{ TNM stage } \\
\hline I & 27 & 12 & 15 & $3.69 \pm 1.45$ & & \\
\hline II & 17 & 6 & 11 & $3.65 \pm 1.57$ & & \\
\hline III & 11 & 0 & 11 & $2.44 \pm 1.32$ & & \\
\hline IV & 5 & 0 & 5 & $2.46 \pm 1.07$ & $0.010^{\mathrm{a}}$ & $0.001^{\mathrm{b}}$ \\
\hline \multicolumn{7}{|c|}{ Histological differentiation } \\
\hline Well & 34 & 15 & 19 & $3.85 \pm 1.33$ & & \\
\hline Moderately & 16 & 3 & 13 & $3.18 \pm 1.66$ & & \\
\hline Poorly & 10 & 0 & 10 & $1.95 \pm 0.86$ & $0.010^{\mathrm{a}}$ & $0.001^{\mathrm{b}}$ \\
\hline \multicolumn{7}{|c|}{ Anatomic localization } \\
\hline Supraglottic & 8 & 2 & 6 & $2.08 \pm 0.96$ & & \\
\hline Glottic & 39 & 14 & 25 & $3.86 \pm 1.45$ & & \\
\hline Subglottic & 13 & 2 & 11 & $2.94 \pm 1.23$ & 0.386 & $0.001^{\mathrm{b}}$ \\
\hline
\end{tabular}

${ }^{\mathrm{a}} \mathrm{P}<0.05 ;{ }^{\mathrm{b}} \mathrm{P}<0.01 ; \mathrm{n}$, number of patients; $\mathrm{P}, \mathrm{CADM} 1$-positive cells; $\mathrm{N}, \mathrm{CADM} 1$-negative cells; CADM1, cell adhesion molecule 1; ANOVA, analysis of variance; TNM, tumor-node-metastasis.
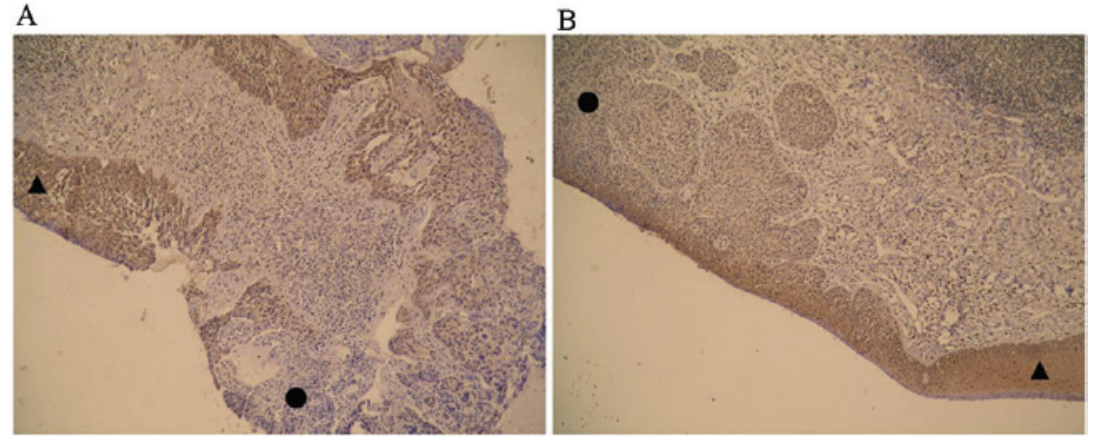

Figure 1. Cell adhesion molecule 1 (CADM1) expression in laryngeal squamous cell carcinoma tumor tissue compared with adjacent normal tissue. (A) CADM1 expression in severe atypical hyperplasia tissue and the absence of its expression in the tumor (magnification, $\mathrm{x} 100$ ). $\boldsymbol{\Delta}=$ Severe atypical hyperplasia tissue, $\bullet=$ tumor tissue. (B) CADM1 expression in mild atypical hyperplasia tissue and the absence of its expression in the tumor (magnification, $\mathrm{x} 100$ ). $\mathbf{\Delta}=$ Mild atypical hyperplasia tissue. $\bullet=$ tumor tissue.

significant correlation between CADM1 protein expression and serum folate levels $(r=0.642, \mathrm{P}=0.001)$. Therefore, folate deficiency may decrease the methylation of $C A D M 1$ promotor and regulate $C A D M 1$ expression. However, further studies are required to confirm this.

\section{Discussion}

In the present study, all included patients were male and most patients aged $<50$ years were TNM stage III or IV with higher serum folate levels, whereas patients aged $>50$ years were stages I-II with lower serum folate levels. The critical factor in the prognosis of LSCC is tumor metastasis, however, the etiopathogenesis of tumor metastasis remains largely unknown and may involve immune dysregulation. CADM1, located on chromosome 11q23.2, encodes a transmembrane protein from the immunoglobulin superfamily (20). Previous studies have demonstrated that CADM1 is a human tumor suppressor and mutations in its cytoplasmic domain have been linked to lung tumor cell metastasis, aggravated histological differentiation, clinical stage classification and a poor prognosis $(6,21,22)$. The results of the present study were consistent with previous studies $(23,24)$ and established that, as compared with adjacent non-neoplastic tissue, tumor tissues express lower levels of CADM1. This is important as CADM1 may serve a potential role in the diagnosis and prognosis of LSCC.

Duthie et al (25) affirmed the effect of folate deficiency on chromosome breaks and the risk of carcinogenesis. Furthermore, it has been determined that folate deficiency 
Table III. Associations between serum folic acid levels in patients with laryngeal squamous cell carcinoma and clinical stage, histological differentiation and anatomic localization.

\begin{tabular}{lccc}
\hline $\begin{array}{l}\text { Clinical } \\
\text { stage } \\
\text { (TNM) }\end{array}$ & P-value & $\begin{array}{c}\text { Histological } \\
\text { differentiation and } \\
\text { anatomic localization }\end{array}$ & P-value \\
\hline I and II & 0.610 & 1 and 2 & 0.110 \\
I and III & $0.002^{\mathrm{a}}$ & 1 and 3 & $0.001^{\mathrm{b}}$ \\
I and IV & $0.001^{\mathrm{b}}$ & 2 and 3 & $0.020^{\mathrm{a}}$ \\
II and III & $0.014^{\mathrm{a}}$ & A and B & $0.001^{\mathrm{b}}$ \\
II and IV & $0.004^{\mathrm{b}}$ & A and C & 0.160 \\
III and IV & 0.320 & B and C & 0.080 \\
\hline
\end{tabular}

${ }^{\mathrm{a}} \mathrm{P}<0.05 ;{ }^{\mathrm{b}} \mathrm{P}<0.01 ; 1$, well-differentiated; 2 , moderately-differentiated; 3, poorly-differentiated; A, supraglottic; B, glottic; C, subglottic TNM, tumor-node-metastasis.

Table IV. Serum folic acid levels in patients with LSCC and healthy controls.

\begin{tabular}{lcc}
\hline Group & $\mathrm{n}$ & Folic acid $(\mathrm{ng} / \mathrm{ml})$ \\
\hline Healthy controls & 30 & $4.40 \pm 1.47^{\mathrm{a}}$ \\
Patients with LSCC & 60 & $3.35 \pm 1.51$ \\
\hline
\end{tabular}

Data are presented as the mean \pm standard deviation. ${ }^{\mathrm{a} P}=0.002 . \mathrm{n}$, number of patients; LSCC, laryngeal squamous cell carcinoma.

may decrease thymidine synthesis and stimulate uracil misincorporation into DNA $(26,27)$. Homeostasis of folate is critical to DNA stability and integrity, as well as the repair of damaged DNA, and folate supplementation may have a protective effect against cancer $(15,16,28,29)$. The results of the current study demonstrated that serum folate levels in patients with LSCC were markedly lower than those in healthy individuals and decreased with the deterioration in the degree of tumor malignancy. This indicates that low serum folate levels may be associated with the increased malignancy of LSCC.

The results of the present study suggested that there was a significant association between CADM1 protein expression and serum levels of serum folate in patients with LSCC $(r=0.642, \mathrm{P}=0.001)$. CADM1 expression varied among different anatomic localizations; therefore, this relationship may result from the different malignant degrees and carcinoma progression. However, the unique microenvironments of different anatomical localizations may also contribute to the difference. Therefore, further studies are required to understand why these differences occur.

The analysis demonstrated that the decline of serum folate levels may be the cause of low CADM1 expression in LSCC tumor tissue. It was observed that a significant proportion of LSCC patients had low serum folate levels. Furthermore, as the severity of LSCC increased, serum folic acid levels decreased. Therefore, folate deficiency may be associated with the excessive consumption of folic acid in the body (due to the increased energy needs of patients with cancer) during repair of the damaged $C A D M 1$ gene (17).

Folate is a critical factor of DNA methylation (29) and methylation of promoter DNA has been regarded as an important mechanism of $C A D M 1$ gene silencing (30). In the present study, CADM1 downregulation in LSCC tumor tissue was observed; however, the underlying mechanism was not investigated. Therefore, further clinical studies are necessary. In future studies, we intend to evaluate the effectiveness of serum folic acid supplementation in patients with LSCC and to identify the intrinsic relationship between folate and promoter methylation of the CADM1 gene.

\section{Acknowledgements}

This study was supported by the Provincial Science and Technology Foundation of Henan Province, China (grant no. 132102310029).

\section{References}

1. Huang XZ, Wang JB and Kong WJ: Practice of Otorhinolaryngology-Head and Neck Surgery. 2nd edition. People's Medical Publishing House, Bei Jing, China, 2007.

2. Murakami Y, Nobukuni T, Tamura K, Maruyama T, Sekiya T, Arai Y, Gomyou H, Tanigami A, Ohki M, Cabin D, et al: Localization of tumor suppressor activity important in nonsmall cell lung carcinoma on chromosome 11q. Proc Natl Acad Sci USA 95: 8153-8158, 1998.

3. Allinen M, Peri L, Kujala S, Lahti-Domenici J, Outila K, Karppinen SM, Launonen $\mathrm{V}$ and Winqvist R: Analysis of 11q21-24 loss of heterozygosity candidate target genes in breast cancer: Indications of TSLC1 promoter hypermethylation. Genes Chromosomes Cancer 34: 384-389, 2002.

4. Fong KM, Kida Y, Zimmerman PV, Ikenaga M and Smith PJ: Loss of heterozygosity frequently affects chromosome $17 \mathrm{q}$ in non-small cell lung cancer. Cancer Res 55: 4268-4272, 1995.

5. Zhou L, Jiang W, Ren C, Yin Z, Feng X, Liu W, Tao Q and Yao K: Frequent hypermethylation of RASSF1A and TSLC1 and high viral load of Epstein-Barr Virus DNA in nasopharyngeal carcinoma and matched tumor-adjacent tissues. Neoplasia 7: 809-815, 2005.

6. Kuramochi M, Fukuhara H, Nobukuni T, Kanbe T, Maruyama T, Ghosh HP, Pletcher M, Isomura M, Onizuka M, Kitamura T, et al: TSLC1 is a tumor suppressor gene in human non-small cell lung cancer. Nat Genet 27: 427-430, 2001.

7. Murakami Y: Involvement of a cell adhesion molecule, TSLC1/IGSF4, in human oncogenesis. Cancer Sci 96: 543-552, 2005.

8. Fukuhara H, Kuramochi M, Fukami T, Kasahara K, Furuhata M, Nobukuni T, Maruyama T, Isogai K, Sekiya T, Shuin T, et al: Promoter methylation of TSLC1 and tumor suppression by its gene product in human prostate cancer. Jpn J Cancer Res Jun 93: 605-609, 2002.

9. Jansen M, Fukushima N, Rosty C, Walter K, Altink R, Heek TV, Hruban R, Offerhaus JG and Goggins M: Aberrant methylation of the $5^{\prime} \mathrm{CpG}$ island of TSLC1 is common in pancreatic ductal adenocarcinoma and is first manifest in high-grade PanlNs. Cancer Biol Ther 1: 293-296, 2002.

10. Kamen B: Folate and antifolate pharmacology. Semin Oncol 24 (5 Suppl 18): S18-30-S18-39, 1997.

11. Friso S and Choi SW: Gene-nutrient interactions and DNA methylation. J Nutr 132 (8 Suppl): 2382S-2387S, 2002.

12. Allen RH, Stabler SP, Savage DG and Lindenbaum J: Metabolic abnormalities in cobalamin (vitamin B12) and folate deficiency. FASEB J 7: 1344-1353, 1993.

13. Sie KK, Medline A, van Weel J, Sohn KJ, Choi SW, Croxford R and Kim YI: Effect of maternal and postweaning folic acid supplementation on colorectal cancer risk in the offspring. Gut 60: 1687-1694, 2011.

14. Jennings BA and Willis G: How folate metabolism affects colorectal cancer development and treatment; a story of heterogeneity and pleiotropy. Cancer Lett 356: 224-230, 2015. 
15. Kim YI: Role of folate in colon cancer development and progression. J Nutr 133 (11 Suppl 1): 3731S-3739S, 2003.

16. Choi SW and Mason JB: Folate status: Effects on pathways of colorectal carcinogenesis. J Nutr 132 (8 Suppl): 2413S-2418S, 2002.

17. Kim YI: Folate and carcinogenesis: Evidence, mechanisms, and implications. J Nutr Biochem 10: 66-88, 1999.

18. Kuramochi M, Fukuhara H, Nobukuni T, Kanbe T, Maruyama T, Ghosh HP, Pletcher M, Isomura M, Onizuka M, Kitamura T, et al: TSLC1 is a tumor-suppressor gene in human non-small-cell lung cancer. Nat Genet 27: 427-430, 2001.

19. Yong M, Yang L, Suyila Q, Han W, Yuan H, Zhao C and Su X: Expression and clinical implications of P53, P63, and P73 protein in malignant tumor of the parotid gland. Turk J Med Sci 44: 875-882, 2014.

20. Yurdakul A, Akyurek N, YIlmaz1 Ş, Karakaya J, Memİs L and Ozturk C: Prognostic impact of matrix metalloproteinases (MMP-9 and MMP-2) and vascular endothelial growth factor expression in non-small cell lung cancer. Turk J Med Sci 42: 281-288, 2012.

21. Uchino K, Ito A, Wakayama T, Koma Y, Okada T, Ohbayashi C, Iseki S, Kitamura Y, Tsubota N, Okita Y and Okada M: Clinical implication and prognostic significance of the tumor suppressor TSLC1 gene detected in adenocarcinoma of the lung. Cancer 98: 1002-1007, 2003.

22. Blount BC, Mack MM, Wehr CM, MacGregor JT, Hiatt RA, Wang G, Wickramasinghe SN, Everson RB and Ames BN: Folate deficiency causes uracil misincorporation into human DNA and chromosome breakage: Implications for cancer and neuronal damage. Proc Natl Acad Sci USA 94: 3290-3295, 1997.
23. Surace EI, Lusis E, Murakami Y, Scheithauer BW, Perry A and Gutmann DH: Loss of tumor suppressor in lung cancer-1 (TSLC1) expression in meningioma correlates with increased malignancy grade and reduced patient survival. J Neuropathol Exp Neurol 63: 1015-1027, 2004.

24. Steenbergen RD, Kramer D, Braakhuis BJ, Stern PL, Verheijen RH, Meijer CJ and Snijders PJ: TSLC1 gene silencing in cervical cancer cell lines and cervical neoplasia. J Natl Cancer Inst 96: 294-305, 2004.

25. Duthie SJ, Grant G and Narayanan S: Increased uracil misincorporation in lymphocytes from folate-deficient rats. Br J Cancer 83: 1532-1537, 2000.

26. Duthie SJ, Narayanan S, Brand GM, Pirie L and Grant G: Impact of folate deficiency on DNA stability. J Nutr 132 (8 Suppl): 2444S-2449S, 2002.

27. Butterworth CE Jr: Effect of folate on cervical cancer. Synergism among risk factors. Ann N Y Acad Sci 669: 293-299, 1992

28. Mason JB and Levesque T: Folate: Effects on carcinogenesis and the potential for cancer chemoprevention. Oncology (Williston Park) 10: 1727-1736, 1742-1744, 1996.

29. Murakami Y: Functional cloning of a tumor suppressor gene, TSLC1, in human non-small cell lung cancer. Oncogene 21: 6936-6948, 2002.

30. Fukami T, Fukuhara H, Kuramochi M, Maruyama T, Isogai K, Sakamoto M, Takamoto S and Murakami Y: Promoter methylation of the TSLC1 gene in advanced lung tumors and various cancer cell lines. Int J Cancer 107: 53-59, 2003. 